\title{
Toenail onychodystrophy of the diabetic foot
}

\author{
Mesut Mutluoglu, ${ }^{1}$ Gunalp Uzun, ${ }^{2}$ Ercan Karabacak ${ }^{3}$ \\ ${ }^{1}$ Department of Underwater and Hyperbaric Medicine, Gulhane Military Medical Academy Haydarpasa Teaching Hospital, Istanbul, Turkey \\ ${ }^{2}$ Gulhane Military Medical Academy Haydarpasa Teaching Hospital, Istanbul, Turkey \\ ${ }^{3}$ Department of Dermatology, Gulhane Military Medical Academy Haydarpasa Teaching Hospital, Istanbul, Turkey
}

Correspondence to Dr Mesut Mutluoglu, drmutluoglu@gmail.com

\section{DESCRIPTION}

A 54-year-old diabetic female patient with type 2 diabetes of 7 years' duration presented with pain in her big toe. She had previously sustained foot ulceration several times and hence worried for recurrence. On examination she had a laminated, thickened, dark yellow toe nail of an extremely rare structure (figure1).

Onychodystrophy, which is a widely used term referring to nail deformities, has historically been linked with several genetic syndromes. ${ }^{1}$ Additionally, it may be associated with fungal and nonfungal infections, various non-infectious inflammatory dermatological diseases, benign and malign neoplasms and systemic drug use. ${ }^{2}$

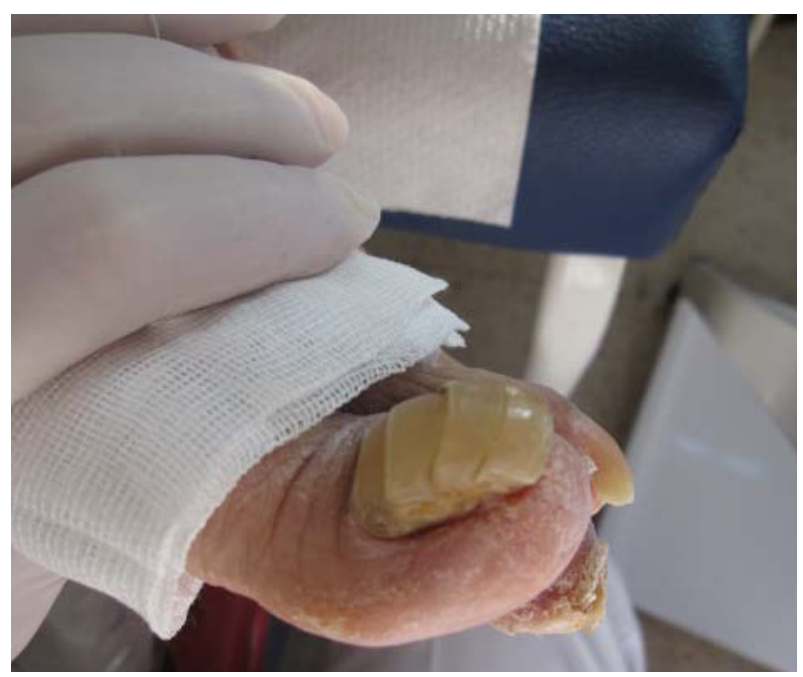

Figure 1 Laminated, thickened, dark yellow toe nail.
None of these conditions was present in our patient. Onychodystrophy is also common among diabetic patients with poor peripheral circulation and/or peripheral neuropathy. It may have severe implications in the diabetic foot and may be the initial cause for several wounds. ${ }^{3}$ Excessive thickening and deformities of the nails may result in an accumulation of debris beneath the nail which may predispose to bacterial growth. Additionally improper shoes may press on the nails and may become the site of ulceration following repeated microtrauma. Once onychodystrophy occurs, it is rather challenging to manage these deformities. Hence, the care of toe nails in the diabetic foot is as important as any other aspects involved in ulceration. Close follow-up and timely interventions may prevent the occurrence of such deformities.

\section{Learning points}

Toe deformities may be the initial cause for several diabetic foot wounds.

- Toe care is as important as the care of the rest of the foot in diabetic patients.

Competing interests None.

Patient consent Obtained.

\section{REFERENCES}

1. Feinmesser M, Zelig S. Congenital deafness associated with onychodystrophy. Arch Otolaryngol 1961;74:507-8.

2. Oppel T, Korting HC. Onychodystrophy and its management. Ger Med SCi 2003;1:Doc02.

3. Millikan LE, Powell DW, Drake LA. Quality of life for patients with onychomycosis. Int J Dermatol 1999;38(Suppl 2):13-16. 


\section{BMJ Case Reports}

Copyright 2012 BMJ Publishing Group. All rights reserved. For permission to reuse any of this content visit http://group.bmj.com/group/rights-licensing/permissions.

BMJ Case Report Fellows may re-use this article for personal use and teaching without any further permission.

Please cite this article as follows (you will need to access the article online to obtain the date of publication).

Mutluoglu M, Uzun G, Karabacak E. Toenail onychodystrophy of the diabetic foot. BMJ Case Reports 2012;10.1136/bcr-2012-007314, Published XXX

Become a Fellow of BMJ Case Reports today and you can:

- Submit as many cases as you like

- Enjoy fast sympathetic peer review and rapid publication of accepted articles

- Access all the published articles

- Re-use any of the published material for personal use and teaching without further permission

For information on Institutional Fellowships contact consortiasales@bmjgroup.com

Visit casereports.bmj.com for more articles like this and to become a Fellow 